\title{
Lessons from the Financial Crisis and Other Banking Scandals
}

By Sue Jaffer (Senior Researcher at La Trobe Law School, Melbourne, Australia), Orcid: https://orcid.org/0000-0003-1859-0814 Nicholas Morris (Adjunct Professor at La Trobe Law School, Melbourne, Australia), Orcid: https://orcid.org/0000-0002-7520-5970

La Trobe University, Melbourne, Australia

\section{ABSTRACT}

The Global Financial Crisis (GFC) had dire implications for the UK, creating massive unemployment and years of austerity. This paper looks at the underlying causes of the crisis, together with the reasons why financial regulation in the UK failed to prevent the financial crash. The UK sought to learn the lessons from its failure, and many inquiries, research reports and books have explored the causes and compounding factors. The book "Capital Failure" identified that trust was fundamental to the working of the financial sector, and that the erosion of trust and trustworthy behaviour has had a disastrous effect. Australia escaped relatively unscathed from the GFC, yet recent inquiries into the banking and superannuation sectors have revealed a similar dramatic decline in trustworthiness and ethical standards of behaviour. The article examines how the Australian banking environment evolved, the implication of recent developments including Fintech and Regtech, and what lessons Australia can learn from overseas experience.

Keywords - Financial crisis, Financial markets, Trust, Accountability, Regulation

Disclosure statement - No potential conflict of interest was reported by the author.

License - This work is under Attribution-NonCommercial-ShareAlike 4.0 International (CC BY-NC-SA 4.0) https://creativecommons.org/licenses/by-nc-sa/4.0/ Suggested citation: Jaffer, S. and N. Morris. 2019. “Lessons from the Financial Crisis and Other Banking Scandals." Law in Context, 36 (1): 47-63. DOI: https:// doi.org/10.26826/law-in-context.v36i1.86

\section{Summary}

1. Introduction and purpose

2. What were the underlying causes of the financial crisis?

3. Why did financial regulation fail in the UK?

4. How did the UK respond?

5. Steps required for a trustworthy financial system

6. Can Fintech and Regtech help to improve trustworthiness?

7. Implications for Australia

8. How did the modern Australian system emerge?

9. Regulation of the Australian system

10. Royal Commission findings

11. What can Australia learn from overseas experience?

12. References 


\section{INTRODUCTION AND PURPOSE}

A period of low global interest rates and a drive by governments and central bankers to encourage home ownership created a major, unsustainable, credit boom. In the US subprime mortgages were "sliced and diced" into collateralised debt obligations, given attractive risk ratings from credit rating agencies, and bought by yieldseeking financial institutions around the western world. Combined with lack of attention to the overall liquidity of the system, these factors combined to cause major institutions, such as Lehman Brothers, to fail.

When US house prices collapsed, mortgage delinquencies caused the failure of these mortgage-backed securities. The collapse in value of the securities led to a liquidity crisis as the quality of banks' lending policies suddenly looked questionable, some US institutions failed, and uncertainty spread as to which financial institutions were most exposed to mortgage losses and liquidity shortages. Short-term wholesale funding disappeared, and the Bank of England had to intermediate to provide daily liquidity. Northern Rock, ${ }^{1}$ which relied heavily on short term wholesale funding, was the first UK bank needing to be bailed-out.

The results of the banking collapse for the real economy in the UK were brutal: lending to and investment by the corporate sector collapsed. The greatest downturn since the Great Depression saw a one million increase in UK unemployment and wages fell by $5 \%$ to below 2007 levels (Bank of England 2019). The sudden collapse in asset values meant that banks had to sell more assets to restore their balance sheets, leading to a vicious cycle of fire-sale prices. The British Government established a Bank Recapitalisation Fund, which provided bailouts to the Royal Bank of Scotland (RBS) of $£ 20$ billion, and $£ 17$ billion to HBOS and TSB.

The cost of the bailouts was borne by taxpayers and the wider community, and many years of austerity began. There was a great deal of anger that bankers had received huge rewards, seemingly unrelated to the value of the work undertaken, which they kept even when the collapse came. There had been no "calling to account"-bankers had effectively privatised their gains and socialised their losses (Lambert 2014). These feelings of anger and mistrust were fuelled also by numerous examples of misselling of financial products and abuse of financial instruments. Pensions and life insurance had been widely missold, and the LIBOR interest-rate fixing scandal in 2012 was the last straw for many.

The Parliamentary Commission on Banking Standards described "a collapse of trust on an industrial scale" (PCBS 2013). The incoming Governor of the Bank of England discussed the "fundamental loss of trust" that followed when banks became more concerned with making profits than helping their clients (Carney 2013). The Archbishop of Canterbury, Justin Welby, argued that "economic crises are a major problem when they're severe. When they are accompanied by a financial crisis and a breakdown in confidence, then they become a generational problem" and the only way to "fix this mess" is through a change in culture (Welby 2013).

In the aftermath of the Global Financial Crisis (GFC), the UK's financial sector was put under the spotlight. Numerous inquiries, reviews, books and academic research projects explored what had caused this catastrophic failure of the UK financial system and what needed to be changed to avoid a repeat. These included a four-year research project at Oxford University in which we participated, and which led to the publication of Capital Failure (Morris and Vines 2016).

By contrast, Australia got off relatively unscathed from the GFC. Financial institutions had much less exposure to sub-prime investments and had much greater liquidity (in part a result of Australia's compulsory superannuation system). The Australian economy was relatively debt free and running budget surpluses. Australian fiscal stimulus (partly in the form of $\$ 900$ cheques given to those on low incomes) helped Australia weather the world-wide recession, aided by the strong stimulus instituted by China.

The praise heaped on Australian banks bred complacency. Former Treasurer Peter Costello said: "In the aftermath of [the GFC] some of these bankers started to believe it was due to their genius, they should take the

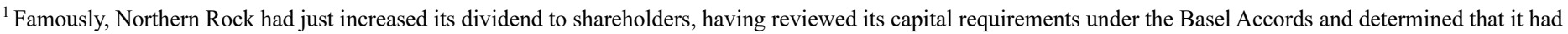
capital to spare.
} 
rewards and they took the eye off the ball which was the customer." (Murdoch 2018). Ten years later, an Australian Royal Commission has, belatedly, exposed many failings in the Australian financial system.

The purpose of this article is to look at the many lessons that were learned in the UK as to what went wrong, what changes were made in response, and what these and the recent Royal Commission's findings imply for financial regulation in Australia.

\section{WHAT WERE THE UNDERLYING CAUSES OF THE FINANCIAL CRISIS?}

Capital Failure attempted to distil the key features/ characteristics of financial institutions, markets and individuals that helped to create the financial crisis (Morris and Vines 2014). It found that lack of regard for trust and accountability was central to what went wrong.

The starting point for this lack of regard was a misplaced belief in efficient markets. Throughout the period of the "Great Moderation", a lightly regulated financial system was thought to work well, even if the individuals operating within the market are selfish.

Adam Smith described the effects of self-interested motivations:

It is not from the benevolence of the butcher, the brewer, or the baker, that we expect our dinner, but from their regard to their interest. We address ourselves not to their humanity but to their self-love ... [The Wealth of Nations, Book IV, chapter 2, para 2]

Furthermore, Smith argued that these self-interested motivations could (in some circumstances) give rise to good outcomes:

Every individual ... neither intends to promote the public interest, nor knows how much he is promoting it .... He intends only his own security; and by directing that industry in such a manner as its produce may be of greatest value, he intends only his own gain, and he is in this, as in many other cases, led by an invisible hand to promote an end which was no part of his intention. [The Wealth of Nations, Book IV, chapter 2, para 9]

Twentieth century economists formalised Adam Smith's insight about "the invisible hand" in the First Theorem of
Welfare Economics. This argued that a well-functioning competitive market will give rise to efficient outcomes-in which no person can be made better off without some other person being made worse off-even if all economic actors are pursuing selfish interests.

Since the Great Depression financial markets had been heavily regulated. That led to credit rationing and many households were unable to borrow. However, as the demand for financial services increased (with the rise of banking and saving, the demand for home-ownership and mortgages, and the encouragement of pensions), policymakers believed that financial markets should be opened up to foster competition and innovation. Mistaken belief in efficient markets meant there was very little focus on the trustworthiness of the financial services provided and the need for financial service providers to be explicitly concerned with the interests of clients (Jaffer, Morris and Vines 2014).

Changes to industry structure and remuneration arrangements conspired to erode the ethical behaviour and the trustworthiness of the financial sector. Systems that exerted peer-group pressure were dismantled, selfregulatory arrangements were replaced with administrative controls and, encouraged by incentivised remuneration, selfish behaviour became widespread. The UK's "lighthanded" regulation became a model for international regimes-with disastrous results.

Why was belief in efficient markets so misplaced for financial services? The answer lies in the characteristics of financial services and products which meant that the strong assumptions required for perfectly competitive markets did not hold (Jaffer et al. 2014). These key characteristics comprise asymmetric information, complexity, uncertainty, moral hazard and conflicts of interest. They gave rise to high leverage on the part of financial firms, excessive risk taking, extraction of economic rents and the mispricing of risk. Moreover, the adverse implications of these characteristics were magnified by remuneration systems and an over-emphasis on shareholder value in capital markets.

The presence of asymmetric information makes financial services trust-intensive. Customers do not have access to the information or expertise needed to assess 
the quality of the products. In addition, many products involve long time frames and uncertain outcomes, making the value difficult to assess over the short and medium term. These problems of asymmetric information worsened as financial products became more complex. Thus, the Turner Review opined:

For it seems likely that some and perhaps much of the structuring and trading activity involved in the complex version of securitised credit, was not required to deliver credit intermediation efficiently. Instead, it achieved an economic rent extraction made possible by the opacity of margins, the asymmetry of information and knowledge between end users of financial services and producers, and the structure of principal/agent relationships between investors and companies and between companies and individual employees.

[The Turner Review 2009, 59]

Not only are financial products often highly risky, but the risk tends to be dispersed amongst multiple players. This diversification served to make knowledge of the product more difficult again, ultimately amplifying the risks.

The fact that customers do not understand the products being sold enables firms to extract monopoly profits, through high fees and high prices for products. Those tasked with assisting consumers, trustees, fund managers or asset managers, may also over-charge or have insufficient expertise to protect their clients (Jaffer, Morris and Vines 2014).

Conflicts of interest arose with the growth of integrated financial institutions. In pre-Big Bang London, the different agents (brokers, fund managers, investment advisors, wealth managers) were largely independent. With the emergence of universal banks, conflicts of interest arose, and the imposition of fiduciary duties became more difficult to sustain (Jaffer et al. 2014). At the retail level, customers were sold unsuitable products. At the wholesale level contract law was used to over-ride the fiduciary duties that would otherwise have applied to so-called "sophisticated customers". Complex products were created and sold without regard to the risk of their failure or the fact that a related party may have had an interest in their failure. The misselling of Lehman bonds to Australian local authorities was one such example (O’Brien 2014).
Remuneration structures also played an important role in eroding trustworthiness. Academic work on the principal-agent problem argued that performance bonuses would align the interests of managers and shareholders. However, in financial services this created incentives for the product provider to take or even manufacture risks because the costs that eventuate fall almost entirely on the customer (O'Brien 2014). Where there is significant uncertainty and asymmetric information, it is relatively easy for managers to set up arrangements that yield high returns for clients (and high bonuses) in the short term, while imposing severe tail risks which may take years to materialise.

Moral hazard also played a role in encouraging the excessive leverage of financial firms. Originally (in the early 1800s), banks in England and Wales were ownermanaged. If a bank failure wiped out depositors, it wiped out the manager-owner too (Davies 2014). However, the link between depositor safety and managers' returns has been weakened over time, with the creation of banks that were "too big to fail" and an implicit government guarantee.

Before deposit insurance existed, depositors had a strong reason to monitor the risky activities of their banks. Furthermore, there was an expectation that banks would bail each other out if there was a liquidity crisis. Capital levels were much higher and leverage correspondingly lower. However high leverage also delivers high returns to shareholders, and high remuneration to executives. Risky investments such as derivatives multiplied. The government's implicit guarantee further encouraged firms to engage in risky behaviour, as taxpayers would cover the cost of catastrophic failure.

Poor corporate governance also played a role. Weak and inexpert boards did not properly understand the risks that were accumulating. Compensation schemes encouraged excessively risky behaviour. Board independence and oversight was eroded as management became more powerful. Weak and inconsistent accounting standards enabled the arbitrage of regulations, and the absence of formal shareholder engagement left management free to pursue their self-serving goals (Arnd and Berg 2010, n. 13). 


\section{WHY DID FINANCIAL REGULATION FAIL IN THE UK?}

Financial regulation failed to keep up with a rapidly changing financial sector. There were errors of omission-most noticeably no-one had identified the implicit subsidies building up as firms became too big to fail. Nor was anyone focussed on the systematic risk in the system as a whole (Jaffer, Knaudt and Morris 2014). Some of the failures were intrinsic to the regulatory process-such as incentives to arbitrage regulatory rules. But some of the problems were seriously exacerbated by regulation itself: regulatory requirements distracted management and contributed to an abrogation of responsibility by key parties. It also produced information that was ill-suited to the needs of users.

The tripartite system of splitting oversight between the FSA, the Bank of England and the Treasury was widely acknowledged to have failed. The Basel Accords were intended to bring risk management up to best practice, but no-one focussed on the implications of the explosion of securitised credit for the risks of the system as a whole (Basel Committee on Banking Supervision 2019).

Arrangements for lender of last resort and deposit insurance were introduced to prevent liquidity problems turning into insolvency. Although it was recognised that moral hazard is created by deposit insurance, the extent of hazard was greatly magnified by the sheer scale of risk-taking. Banks became "rationally careless" about the pricing of risk and the market for risk ceased to work (Wolf 2011).

The Basel Accords required a capital minimum of $8 \%$ of total assets for banking institutions. However, the weights used to reflect relative riskiness were arbitrary and did not allow for the fact that the assets were illiquid. Furthermore, they served to blind management to the true riskiness of their business. For example, Northern Rock had borrowed heavily in wholesale markets to fund its mortgage portfolio. After announcing that it was compliant with Basel II, Northern Rock promptly increased its dividend payout. Shortly afterwards the demand for its mortgage backed securities collapsed and Northern Rock became insolvent.
Further regulatory failures stemmed from the belief in efficient markets. Regulators believed that greater disclosure of information could counteract information asymmetries. Instead users were swamped with information which exacerbated existing cognitive biases. Gatekeepers, such as auditors and Credit Ratings Agencies (CRAs) suffered from a lack of independence, while securitisation itself reduced the amount of information available to investors.

Similarly, the FSA had been reluctant to regulate financial products, in fear that product regulation would stifle innovation and reduce choice for customers. Instead reliance was placed on conduct of business rules, with customers assumed to choose products that suited their needs. This approach failed at both the wholesale and retail levels, with pricing for ill-conceived products detached from true risks. At the same time, the ever-increasing complexity of products weakened the ability of boards and regulators to implement and enforce appropriate controls and further weakened the effectiveness of disclosure.

\section{HOW DID THE UK RESPOND?}

One of the first regulatory reviews after the GFC was the Turner Review, which examined the growing scale and complexity of banks, and found poor risk management, inadequate boards, remuneration policies that encouraged excessive risk taking, conflicts of interest amongst the rating agencies and a lack of understanding on the part of investors of products and their associated risks (FSA 2009). Its recommendations included measures to improve banks' capital adequacy and liquidity, and reduce leverage, a bank resolution regime to ensure the orderly wind down of failed banks, revisions to remuneration policies, a shift in the FSA's supervisory approach to focus on risks and outcomes, technical skills and probity, and the introduction of counter-cyclical capital and liquidity measures.

The Independent Commission on Banking, headed by Sir John Vickers, was asked to look at how to reduce systemic risk, mitigate moral hazard, reduce the likelihood and impact of firm failures, and make recommendations regarding competition in the banking sector. The Vickers Report recommended that UK banks' retail operations 
should be "ring fenced" to insulate them from riskier investment banking activities, secure their continued operation in the event of failure and reduce the costs of bailouts (ICB 2012). The Commission also made recommendations intended to improve the loss-absorbency of UK banks and improve competition in the banking sector through the divestiture of Lloyds Banking Group, making the cost of bank accounts more transparent and easing the process of switching.

David Walker was asked to review corporate governance in UK banks, in the light of the failure of the banking system. The Walker Report set out a series of recommendations intended to establish new ethical standards for bank behaviour (Walker 2009). It called for active and accountable boards, capable of questioning management's approach to risk, more intrusive supervisory roles for regulators in the governance of risk, and enhancements to remuneration controls.

The FSA's report on the failure of the Royal Bank of Scotland (RBS) found that executives and the board made "a series of bad decisions", but that there was no fraudulent or dishonest activity (FSA 2011). In particular, the FSA concluded that their actions were not sanctionable in the absence of any codes or standards against which to judge their performance. However, the report was controversial, and was itself reviewed by the House of Commons Treasury Committee. Their report found limitations in the FSA's ability to assess the failures of executives and the board as well as finding governance issues in the regulator itself (HCT 2011).

Subsequently the FSA was disbanded and replaced by two new regulatory entities. The Financial Conduct Authority (FCA) now regulates the conduct of 58,000 financial services firms and financial markets in the UK. It aims to ensure that financial markets work well, and consumers get a fair deal, through consumer protection activities, enhancing market integrity and promoting effective competition. The Prudential Regulation Authority (PRA) is part of the Bank of England and is the prudential regulator of around 1,500 banks, building societies and other financial entities.

Following the LIBOR scandal, ${ }^{2}$ the Parliamentary Commission on Banking Standards was established to inquire into professional standards and culture in the UK banking sector, and to make recommendations for legislative and other reforms. The Commission's Final Report, Changing Banking for Good, addressed the responsibilities of senior executives and the board of directors (PCBS 2013). The recommendations sought to make executives and board members fully accountable for their decisions and the standards of their banks, through a new licensing regime underpinned by Banking Standards Rules, a "Senior Persons Regime" with enforcement powers and a new criminal offence for reckless mis-conduct in the management of a bank, a new remuneration code to better align risks and rewards, and powers for the regulator to cancel all outstanding deferred remuneration for senior bank employees in the event that their banks need taxpayer support.

The Basel Accords are being revised and efforts to apply regulation to the shadow banking sector are underway. In addition, the Financial Conduct Authority (FCA) is planning much more intrusive product regulation to protect customers, to intensify supervision of risk mitigation, improve redress to customers and change incentives where necessary.

The many other reports and investigations into the GFC are too numerous to mention. They include reports, articles and speeches by senior regulators and researchers at the FCA, the Bank of England, independent think tanks and government entities and parliamentary committees. The many academic contributions include Rajan's Fault Lines (Rajan 2010), The Future of Finance (Turner et al. 2010), and our book Capital Failure: Rebuilding Trust in Financial Services (Morris and Vines 2014).

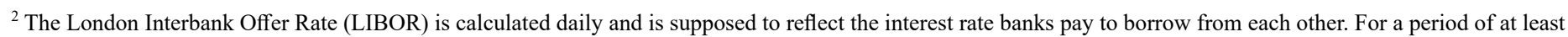

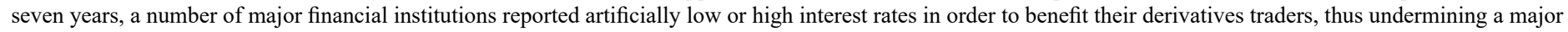
benchmark for interest rates and financial products.
} 


\section{STEPS REQUIRED FOR A TRUSTWORTHY FINANCIAL SYSTEM}

Trust is crucial to the workings of the financial sector. When customers purchase a financial asset, they expose themselves to the risk that the promised returns will not be delivered or that the asset will lose much of its value at some point in the future. Thus, the purchasers need to trust the provider that a good return will be received (Jaffer, Morris and Vines 2014). In the absence of trust, potential purchasers will invest less in financial assets, to the detriment of both the industry and the economy.

For the reasons outlined above, the trustworthiness required of the financial sector requires a stronger form of trust than the economist's view that a person can be trustworthy even if they are motivated by self-interest. Indeed, although Adam Smith is famous for his characterisation of the "invisible hand", he in fact placed great emphasis on "other-regarding" motivations. His Theory of Moral Sentiments opens as follows:

How selfish soever man may be supposed, there are evidently some principles in his nature, which interest him in the fortunes of others, and render their happiness necessary to him, though he derives nothing from it except the pleasure of seeing it. (Smith 1776/1976)

Such other-regarding motivations can arise for different reasons. They can come from "pro-social" motivations, where people are altruistic and seek outcomes which are good for other people. They can come from procedural motivations, such as professionalism, which require that a task be undertaken well and according to accepted standards. Lastly, they can follow from a desire for approbation-Adam Smith's understanding of human motivation (Gold 2014).

From this distinction between self-interested and other-regarding motivations there follows the distinction between weak trust and strong trust (and trustworthiness). Weak trust emerges even under self-interested motivations. However strong trust, and strong trustworthiness, emerge only if there are other-regarding motivations.

In the financial sector, trustworthy behaviour cannot be sustained by weak trust alone. As shown by Noe and Young, it is difficult to detect dishonesty in the presence of uncertainty. Those purchasing products need to rely on other-regarding motivations since dishonest behaviour is unlikely to be apprehended (Noe and Young 2014).

In many situations, individuals will have a multiplicity of motivations, so that framing can be used to encourage other-regarding motivations. In particular, adjustments to legal and regulatory frameworks can be used to adjust the way that issues are perceived by the key agents. For example, fiduciary duties have often been attenuated or eliminated altogether by contractual agreements which give financial intermediaries too much power and create incentives for incompetent or predatory behaviour (Getzler 2014). Reining in the trend to cut back fiduciary duties and clarifying the nature of such duties and remedies would encourage professional motivations in the financial sector.

Codes of conduct can also be used to influence motivations, and are part of the task of professionalising the industry (de Bruin 2014). To be effective in influencing norms of behaviour, however, codes of conduct need to embed values which are important to individuals. These include fairness, integrity, objectivity, competence, confidentiality, professionalism and diligence.

Capital Failure (2014) identifies accountability as a key issue for the financial sector. Some observers see formalised structures of accountability as an alternative to trust. The managerial approach to accountability typically employed sets standards/targets for performance and then measures success through a "tick box" approach. However, ticking boxes cannot substitute for informed judgement of performance and even well-chosen indicators can create perverse incentives. An intelligent system of accountability supports rather than supersedes the placing of trust. It provides good evidence as to whether it is likely the claims of the person or institution seeking to be trusted are true.

O'Neill (2014) suggests that an intelligent system of accountability comprises a definition of required actions: a set of obligations or duties of those who ask to be trusted. Intelligent accountability then imposes an obligation on individuals/organisations to render an account of their performance. It also requires informed and independent judgement on the adequacy of performance, and the communication of evidence on performance by those 
responsible for holding to account. O'Neill argues that well-structured professions and institutions can support the meeting of obligations, in a way that managerial accountability cannot. But genuine professional integrity grows out of strong institutional structures. These include many of the things that have been lacking in financial services: institutional and financial separation, robust systems for dealing with conflicts of interest, serious remedies for failure, and support for professional culture.

The financial sector has thrown up many obstacles to trustworthiness:

a. The emphasis given to shareholder value has encouraged short-term profit maximisation at the expense of trustworthy behaviour

b.High leverage has reinforced the incentives to take excessive risks, since shareholders gained all of the upside, but their downside was limited (as it was shared with credit holders and taxpayers)

c. Remuneration structures have worked directly against trustworthy behaviour by rewarding the creation of tail risk

Many of the regulatory responses that have emerged in the UK are important in terms of addressing these. Remuneration proposals have focused on the need to align incentives with the long-term interests of banks and their shareholders. However, these will only encourage strong trustworthiness if financial institutions articulate the standards which are expected from those who work for them, and if their remuneration standards reflect these standards. The Parliamentary Commission into Banking Standards warned of the difficulty of aligning incentives with the interests of others, with potential for gaming remuneration criteria and rules, the ability of sales-based remuneration to continue informally, and the complications that ensue as staff move between employers (PCBS 2013).

Proposals such as the retail ring fence seek to limit the extent of the government guarantee, with proposals that target high leverage seeking to ensure that the consequence of risk taking are borne by shareholders.

However, few of the reforms are aimed at encouraging strong trustworthiness directly. What is required is a structure of accountability which covers four key steps:

1. A description of the obligations to be delivered
2. Identification of the responsibilities of different players

3. Establishment of mechanisms to encourage and enforce trustworthiness

4. Rendition of an account of performance and methods of holding the individual to account for that performance.

Part of the public's anger over the role of the banks in the GFC rests on the failure of those concerned to take responsibility for their actions. For example, under questioning by the Financial Crisis Inquiry Commission, Lloyd Blankfein, Chairman and CEO of Goldman Sachs claimed that "the standards at the time were different." (Harrington 2011). He did not admit to a lack of personal responsibility, or to a failure in fiduciary duty, or to any public obligation on the part of either himself or his banking colleagues.

The third step is to establish the mechanisms intended to secure and support the delivery of obligations. A wide range of such mechanisms has been used by professions and organisations, including codes of conduct, reputational indices, membership and powers of exclusion, and fraud investigation units. Different mechanisms work to support different types of strong trustworthiness: for example, membership of a professional association and codes of conduct seek to encourage procedural motivations. Reputational indices and fraud investigations support motivations based on esteem and approbation. Ethics committees and ethics training are designed to support pro-social motivations directly. These mechanisms can be reactive (such as exclusion upon wrong-doing) or preventative (e.g. education, elimination of conflicts of interest). Mechanisms to redress transgressions need to be proportionate, but at the same time provide serious remedies for failure.

The final step is to require those with responsibility to render an account of the adequacy of their performance in delivering their obligations, and to hold them to account for that performance. It requires an informed and independent judgement about what has been done (in comparison with what ought to have been done), and this assessment needs to be communicated in an accessible manner. While recent proposals address obligations, responsibilities and enforcement, there has been relatively 
little consideration of how performance can or should be judged intelligently.

\section{CAN FINTECH AND REGTECH HELP TO IMPROVE TRUSTWORTHINESS?}

In more recent years, technology has transformed the way banking is done (often dubbed Fintech). Online banking is now the norm in developed countries, card payments are increasingly automated, and smartphones are used for many purchases (Pikkarainen et al. 2004). New technologies are enabling person-to-person (P2P) payments, with Apple, Google and Venmo following Paypal in providing these services. Banks increasingly use technology to enable Customer Relationship Management (CRM), and improve their assessment of lending risk. Loan origination systems (LOS) are enabling community banks to expand their commercial and industrial loans (Shevlin 2019). These changes have improved financial inclusion and efficiency, and reduced banking costs. But they have also introduced greater opacity into the system and reduced personal interaction between bankers and their customers.

Technologies that have yet to have their full impact include Blockchain and Artificial Intelligence (AI). AI is being embodied into many banking systems, with machine learning now used to identify potential commercial credit request needs, validate credit, perform vendor order execution and enhance CRM. Chatbots are now used extensively for account opening and in marketing. As their use grows, the ability of regulators to understand evolving bank processes is likely to be reduced.

The use of technology to facilitate regulation (RegTech) is emerging both by the regulators themselves and by financial institutions. The automation of due diligence, using data that is tailored to each firm's risk management, is now becoming the norm. In March 2015, a report by the UK Government Chief Scientific Adviser (2015) stated that

FinTech has the potential to be applied to regulation and compliance to make financial regulation and reporting more transparent, efficient and effective - creating new mechanisms for regulatory technology, RegTech.

\section{IMPLICATIONS FOR AUSTRALIA}

Although Australia is connected to the global financial system, and is affected by global events, it has many features which make it unique and somewhat separate. The evolution of Australia's financial system, and its regulation, has been somewhat haphazard. Repeated changes of government within a short electoral cycle, and a tendency to reverse policies set by previous administrations, have led to some incoherence. Australian politicians and regulators have, in the main, been unwilling to challenge the dominant banks and other financial institutions, and Australian requirements on disclosure lag the rest of the developed world. Misguided policy choices have led to a collusive oligopoly of the main banks, which are only lightly regulated by multiple regulators, and an overly complex industrial structure. Importantly, the introduction of compulsory superannuation contributions has created a large and complex industry for the management of pension fund assets which has in turn eroded personal savings.

Australia was slow to implement the reforms which followed the GFC in other countries. Because Australia's government stepped in with a guarantee of all new borrowing, ${ }^{3}$ the GFC did not provide the impetus for reform which emerged elsewhere. Australia was also less exposed to the risks which led to the GFC, partly because superannuation contributions had led to a substantial accumulation of wealth managed by the major institutions (thus strengthening their balance sheets and providing liquidity), and partly because the Asian financial crisis had reduced the industry's appetite for risk. It is only in the last few years, following exposure of various particularly troubling scandals, that Australian politicians have focused on improving the trustworthiness of the industry. It is now clear that similar problems to those which overwhelmed the UK, US and Europe do exist in Australia, and that steps need urgently to be taken to improve the trustworthiness of the financial sector.

\footnotetext{
${ }^{3}$ Allowing the banks to use the Commonwealth Government's AAA credit rating created a "bailout" estimated to be worth A $\$ 120$ billion, see Verrender (2017).

${ }^{4}$ In 1953 banks accounted for 88 per cent of the total assets managed by financial intermediaries (Edey and Gray 1996, p. 4).

${ }^{5}$ Comprising insurance, superannuation funds and investment vehicles such as unit trusts.
} 


\section{HOW DID THE MODERN AUSTRALIAN SYSTEM EMERGE?}

The development of the wider Australian financial services industry prior to 1970 occurred to some extent through trial and error, with changes to investment strategies and industry structure responding to the booms and busts of the business cycle. First equities, then property, then metals, then specialist and international funds, waxed and waned in popularity as bubbles inflated and burst. Increasing internationalisation, following trends in UK, US and Canada, encouraged local innovation and in due course the entry of foreign players to the Australian marketplace (Fraser 1994, p16).

The extensive deregulation of the banking industry which followed the Campbell Inquiry in the 1980s permitted banks to sell life products and also to take over life companies (Commonwealth (1981). This combined with technological innovation and privatisation to generate a steep rise in the size of the financial services sector, from around $100 \%$ of GDP in the early 1980 s to over $200 \%$ by 1992 (Edey and Gray 1996, p .6).

New banks and other financial institutions, including foreign-owned, entered the market and life offices grew rapidly, with some demutualisation. This began a process through which the major banks re-established their dominance, both through organic growth and through acquisitions.

Life companies, in response, diversified into other financial markets, and even entered the banking sector themselves. International banks (such as Citibank and HSBC) entered the market, and established new non-bank financial institutions (NBFIs) both separately and in joint venture with local banks. Financial deregulation also triggered a credit boom, which contributed to the growth of the sector, and fuelled asset price rises which in turn enabled investment funds to achieve exceptional returns.

The Australian financial system thus changed from a closed structure focused mostly on traditional banking activities in the 1950 s and $1960 s,{ }^{4}$ albeit with a vibrant life insurance industry and a relatively small managed funds sector serving wealthier customers, ${ }^{5}$ to a much larger multi-layered system with a wide array of providers and intermediaries. As in the UK, this change occurred in response to growth in demand for financial services from a wider range of customers, driven by increasing wealth among middle-class families, increased desire to save in anticipation of greater longevity, concern to avoid the effects of inflation, and to optimise taxation. However, the changes were also guided by numerous political and regulatory interventions, notably deregulation (in the 1980s), the introduction of award superannuation and industry funds (from 1986), compulsory superannuation contributions $^{6}$ (from 1991 onwards), and the privatisation of state-owned financial institutions.

The introduction of compulsory superannuation contributions was intended to provide a well-financed retirement for Australia's people ${ }^{7}$. However, there is today a growing sense of unease about the level of retirement income that the system will provide (Hewett 2010), a lack of trust in the industry and its advisers (Brandweiner $2012)^{8}$, and a steep rise in the numbers of those who are choosing self-management of their superannuation fund. ${ }^{9}$

The introduction of compulsory contributions was in part necessary because Australia had been slow to introduce effective state provision for those not in the public sector or in the larger companies that ran their own schemes. Australia had a worse problem of poverty among the old than most other OECD countries, and a particularly poor income replacement rate for retirees. In the late 2000's, Australia's income replacement rate for the over 65's was the lowest among 34 OECD countries (69\% of national mean income compared with the OECD average of $86.2 \%$ ) (Pascuzzo 2014).

The 1997 Wallis Committee reported on the Australian Financial System, including superannuation arrangements. ${ }^{10}$ The inquiry considered, inter alia, changing

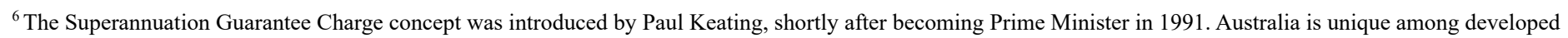
countries in requiring all employees to make such contributions.

${ }^{7}$ A statement of the political intent behind this decision is to be found in Dawkins (1992).

${ }^{8}$ See Brandweiner (2012). Concern about lack of trust is sometimes also expressed by advisers, see, e.g, Brown (2012).

9 Through self-managed superannuation funds ("SMSFs"), Slattery (2011).

${ }^{10}$ See Hanratty (1997) for a useful summary and critique.
} 
customer needs, technology driven innovation, regulation as a driver of change, the changing financial landscape, cost and efficiency, conduct and disclosure, financial safety, stability, co-ordination and accountability, and deregulation. The Wallis Committee recognised that the nature of these investments meant that households would bear a greater proportion of risk directly than they had done in the past. The Committee recommended greater encouragement of member choice in superannuation as a solution. ${ }^{11}$

The Wallis Committee recommendations led to the Financial Services Reform Act 2001 (FSRA). This introduced new licensing provisions and mandatory product disclosure rules in an attempt to introduce consistency across different types of financial product. ${ }^{12}$ The result was that regulation of the products and operations of fund managers became more aligned with wealth management products (insurance, investments and superannuation) than with that of securities and securities dealers. The FSRA also replaced the provisions of the Insurance (Agents and Brokers) Act 1984 to impose stricter disclosure requirements on life insurance companies. ${ }^{13}$

The Australian superannuation system is complex, with over half a million funds of many different types, over 300 platform products, and with extensive outsourcing of key functions to numerous intermediaries. Complexity, lack of disclosure of investment costs, and many degrees of separation between fund members and those who manage their funds, have emerged as serious problems, as have principal-agent, conflict of interest and rent extraction issues. Combined with weak competitive pressures and governance systems, and insufficient legal and regulatory constraints, the result is a system that does not serve its members well.

Recent empirical estimates suggest that over the last twenty years, the Australian superannuation industry has delivered some $\mathrm{A} \$ 700-900$ billion less return for its members than it could have if the compulsory contributions had simply been invested in a passively-managed balanced fund. ${ }^{14}$ The problems which have led to this outcome include a history of incoherent policy processes; fees and charges which are high by international standards; extensive outsourcing; and multiple funds per member which have increased costs and reduced focus. In Australia, legal, regulatory and governance systems appear to have been inadequate to curtail rent-seeking behaviour by advisers and managers.

There are many pivotal moments when key policy decisions were made, including decisions to outsource administration and management of the industry funds, the privatisation of the state-owned banks and insurers, deregulation of the financial services industry, and the development (and repeated variation) of tax concessions for superannuation. Subsequently, policy responses to the various inquiries into the system, in the face of persistent lobbying by an increasingly influential industry, reinforced these early decisions. The wholehearted acceptance of market-driven approaches under the Clinton and Blair administrations in the US and UK during the 1990s also provided justification, albeit misguided, for Australian policymakers. $^{15}$

\section{REGULATION OF THE AUSTRALIAN SYSTEM}

The legislation which followed the Wallis Inquiry set up the current regulatory structure, which consists of five regulatory agencies: $A S I C, A P R A$, the ATO, the Reserve Bank of Australia (RBA) and the Australian Competition and Consumer Commission (ACCC). The ATO has responsibility for smaller funds, with less than four members, the RBA is responsible for financial system stability and for the regulation of the payments system, ${ }^{16}$ and the ACCC has various powers to protect competition in the financial

\footnotetext{
${ }^{11}$ The Commonwealth Government had previously announced a policy of choice of fund in 1996 and introduced a detailed proposal in the 1997 Budget. The relevant Bill was defeated in the Senate in August 2001 but reintroduced in 2002. Select Committee on Superannuation, Parliament of Australia (2002).

${ }^{12}$ Explanatory Memorandum, Financial Services Reform Bill 2001 (Cth).

${ }^{13}$ This reinforced the provisions of the Insurance Act 1973 (Cth) and the Life Insurance Act 1995 (Cth), which require a registration system and also provide for basic supervision of insurers, brokers and agents.

${ }^{14}$ For a more detailed discussion of the problems with the Australian Superannuation system, including these estimates, see Morris (2018).

${ }^{15}$ For further discussion of how misguided beliefs in efficient markets misled policymakers, see Greenspan (2008), Borio (2009), Raghuram (2010).

${ }^{16}$ Through the Payments System Board under new legislation, the Payment Systems (Regulation) Act 1998 (Cth) and the Payment Systems and Netting Act 1998 (Cth).
} 
system (although it has no direct remit for consumer protection).

ASIC was given additional responsibility in 1998 to regulate the market for financial products and services. ${ }^{17}$ It now enforces legislative provisions relating to investments, insurance, superannuation and deposit-taking activities (but not lending); is responsible for the registration of companies, auditors and liquidators; supervises futures markets; implements the provisions of the FSRA; monitors and assesses compliance with a variety of codes of practice; ${ }^{18}$ and has a range of market integrity and consumer protection responsibilities. ${ }^{19}$ ASIC is funded by the Commonwealth Government, although it also receives fees and charges from companies.

APRA commenced operations on 1 July 1998, as a result of the Australian Prudential Authority Act $1998 .{ }^{20}$ APRA is largely funded by industry levies, and is supervised by a full-time executive group of between three and five members appointed by the Governor General. APRA is responsible for the prudential regulation of Authorised Deposit-taking Institutions (ADIs) (banks, building societies and credit unions) ${ }^{21}$ as well as friendly societies, life and general insurance companies, and superannuation funds. It has powers to revoke licences, issue enforceable directions and in extreme cases to intervene in management.

The commercial law framework for superannuation funds in Australia is based on the law of trusts. Superannuation funds are usually "express trusts" and the trustees of superannuation funds are in principle "status-based" fiduciaries. ${ }^{22}$ Prime responsibility for the viability and prudent operation of the superannuation fund rests thus with trustees. Trustees may be either a company with a Board of Directors or a group of people (who may also be the members). Trustees, in their role as fiduciaries, are in principle subject to an "inflexible rule" which prevents them putting themselves in a position where their interest and duty conflict. ${ }^{23}$

Trust law does provide some protection to members, though this is constrained in various ways. In the Australian superannuation industry, enforcement of the provisions of the SIS Act mostly concern breaches relating to malfeasance by individuals, which can give rise to a civil penalty order or criminal liability. ${ }^{24}$ Other breaches can in principle result in the superannuation fund losing its complying fund status, and hence its privileged tax status. ${ }^{25}$ The main effect of the latter could be that members transfer assets to another, complying fund. Individuals may also be barred from acting as directors. ${ }^{26}$

Recent inquiries have suggested that the financial and superannuation systems need to be made more efficient and accountable and have suggested reforms. These include the Ripoll Inquiry into corporate scandals and failures (following the GFC) ${ }^{27}$ and the Super System Review (ibid.). The recent Financial System Inquiry ${ }^{28}$ has led to both the Reserve Bank of Australia and the Australian Treasury, questioning whether the transfer of risk to members and the large costs of the system are appropriate. ${ }^{29}$

\footnotetext{
${ }^{17}$ This is the role that the Wallis Inquiry envisaged for the CFSC.

${ }^{18}$ Including the Code of Banking Practice, the Credit Union Code of Practice, the Building Society Code of Practice and the Electronic Funds Transfer Code of Practice.

${ }^{19}$ ASIC took over these roles from the ISC and from the ACCC.

${ }^{20}$ APRA was intended to carry out the role that the Wallis Inquiry envisaged for the APRC.

${ }^{21}$ Under the depositor protection provisions of the Banking Act 1959 (Cth). All ADIs are required to hold assets in Australia at least equal to their deposit liabilities in Australia.

${ }^{22}$ But see Edelman (2013). Edelman notes that the courts usually regard status as simply informing about what the fiduciary has undertaken to do, see Beach Petroleum $v$ Kennedy (1999) 48 NSWLR 1, 188.

${ }^{23}$ See Bray v Ford [1896] AC 44, 51; Phipps v Boardman [1967] 2 AC 46, 123; Glover (2002).

${ }^{24}$ Donald (2013); SIS Act pt 21.

${ }^{25}$ Income Tax Assessment Act 1993 (Cth) pt IX.

${ }^{26}$ Corporations Act 2001 (Cth).

${ }^{27}$ Parliamentary Joint Committee on Corporations and Financial Services (2009).

${ }^{28}$ The Financial System Inquiry, chaired by David Murray AO, was announced by the Prime Minister, Tony Abbott, on 20 November 2013; see Prime Minister of Australia (2013).

${ }^{29}$ Reserve Bank of Australia (2014); Department of Treasury (2014).
} 
In 2017, a Senate inquiry began into a scandal whereby planners working for Commonwealth Financial Planning (CFPL), a subsidiary of CBA, were accused of putting clients' money into risky investments without their permission, and forging documents. ASIC was also accused of being complacent in its investigation of the rogue financial planners (McGraph and Janda 2014). The inquiry recommended that a Royal Commission be established to investigate this and other questionable behaviour in the financial sector.

\section{ROYAL COMMISSION FINDINGS}

Although the Ripoll Inquiry, which was triggered by the collapse of Storm Financial, highlighted many concerns over the trustworthiness of the Australian industry, its founder Bernie Ripoll still believes that the problems have not been addressed.

When it comes to financial services, people don't trust the system or the sector, or for that matter, really, government to be able to protect them fully and properly. Financial planning doesn't have professional standards, a code of conduct, defined educational standards and the commitment to a fiduciary type duty to customers that real professions have. (Bernie Ripoll 2018, quoted in Robertson 2018, p. 4).

This conclusion was reinforced by the findings of the Royal Commission, which reported on 4th February 2019. The report highlighted:

conduct by many entities that has taken place over many years causing substantial loss to many customers but yielding substantial profit to the entities concerned. Very often, the conduct has broken the law. And if it has not broken the law, the conduct has fallen short of the kind of behaviour the community not only expects of financial services entities but is also entitled to expect of them. (Royal Commission 2019, 1)

And placed the blame squarely on the shoulders of the management of the financial services industry:

There can be no doubt that the primary responsibility for misconduct in the financial services industry lies with the entities concerned and those who managed and controlled those entities: their boards and senior management. (Royal Commission 2019, 4)

The Royal Commission heard cases of customers being charged for services they had never received, and people being charged these fees even after they had died. The final report made 76 recommendations for reform, and suggested more than 20 prosecutions involving the major banks, at the discretion of the regulators, some criminal, some civil, and some both. The regulators were put on notice to perform better, and if ASIC did not prosecute more often the Commission recommended that it become simply an investigative body, with prosecuting powers granted to some other body.

In response to the Commission, the Australian government has committed to introducing legislation which ensures that mortgage brokers will be required to act in the best interests of borrowers, that conflicts of interest between brokers and consumers will be removed by banning trail commissions and other inappropriate forms of lender-paid commissions on new loans from 1 July 2020, and ensuring superannuation fund members only have one default account (for new members entering the system). It also committed to protecting vulnerable consumers by clarifying and strengthening the unsolicited selling (antihawking) provisions, prohibiting deduction of any advice fees from MySuper accounts.

The ASIC Chairman, James Shipton, noted "the serious matters referred by the Royal Commission of possible breaches of financial services laws" and committed to prioritising these investigations. ${ }^{30}$ In February 2019 ASIC published a detailed update on implementation of the Royal Commission recommendations. ${ }^{31}$ It is committed to implementing all of the 46 recommendations in its area of responsibility, including 11 that will extend ASIC's remit and powers, and 23 recommendations which will impose new requirements or restrictions on the entities regulated by ASIC. A new system of Close and Continuous Monitoring (CCM) was initiated in 2018.

APRA responded positively to the Royal Commission, agreeing that there are a number of areas where APRA's

\footnotetext{
${ }^{30} \mathrm{See}$ https://asic.gov.au/about-asic/news-centre/find-a-media-release/2019-releases/19-020mr-statement-from-asic-chair-james-shipton-on-the-final-report-of-theroyal-commission-into-misconduct-in-the-banking-superannuation-and-financial-services-industry/

${ }^{31} \mathrm{https}$ ://download.asic.gov.au/media/5011933/asic-update-on-implementation-of-royal-commission-recommendations.pdf

${ }^{32} \mathrm{See}$ https://www.apra.gov.au/media-centre/media-releases/apra-responds-royal-commission-final-report

${ }^{33}$ Detailed responses are available at https://www.apra.gov.au/sites/default/files/table_with_apras_responses_to_royal_commission_recommendations-v1.pdf

${ }^{34} \mathrm{See} \mathrm{https://www.afr.com/business/banking-and-finance/rba-treasury-warn-regulatory-response-to-hayne-commission-risks-credit-crunch-20181001-h16322}$
} 
prudential and supervisory framework can and should be strengthened. ${ }^{32}$ It has provided detailed responses both to the Commission's recommendations, and to the Government's response. In most cases, suitable changes to regulation are being implemented. ${ }^{33}$ Importantly, it has committed to publishing accountability statements consistent with the Banking Executives Accountability Scheme (BEAR) by the end of 2019.

The Reserve Bank of Australia (RBA), while also welcoming the Commission's work and findings, cautioned against a too-severe regulatory response which might curtail lending to home buyers and business. ${ }^{34}$ However, the RBA accepted that "culture and governance within financial institutions need improving" (RBA 2019, p. 4).

\section{WHAT CAN AUSTRALIA LEARN FROM OVERSEAS EXPERIENCE?}

Although there have been numerous previous inquiries into both the Australian superannuation and wider financial services industries, it has taken a Royal Commission to highlight how many of the problems exposed by the GFC also exist in Australia. Relying on trustworthiness of advisers, managers, trustees and board members does not seem to be sufficient to protect consumers and pension fund members. We believe that unless strong trustworthiness can be created in the financial industry, the problems that clearly exist throughout the system will continue to be detrimental.

The complexity of the Australian industry, and of the contractual structures it relies on, make the identification and prevention of de facto collusive behaviour and anti-competitive use of cross-subsidies very difficult for regulators (such as the Australian Competition and Consumer Commission (ACCC), the Australian Securities and Investments Commission (ASIC), and the prudential regulators), or the courts to identify and combat.

Unfortunately, fiduciary duty is frequently set aside in Australian financial services, where apparently wellinformed consent is given, and the courts have usually regarded contracts as taking precedence over fiduciary duties. In addition, trust law has limited effectiveness in a world of member choice and flexibility of trust deed (Donald 2007). Trustees' fiduciary responsibilities therefore need to be strengthened.

Because of the vast funds which have been accumulated since the introduction of compulsory superannuation contributions, the financial services industry in Australia, and its potential for untrustworthy behaviour, is to a large extent focused on superannuation funds. A further market failure which requires regulatory intervention is the difficulty that members have in acquiring suitable products to help them manage risk. Their need to do this on an individual basis has been created by the choice of Defined Contributions (DC) as the main basis for Australian superannuation. As a result, individuals face both longevity and market risks (including the risk of needing to pay excessive fees because of principal-agent, conflict of interest and rent-seeking problems).

There are too many regulatory agencies, with inadequate focus on the costs imposed by financial institutions. Various legislative changes have weakened the force of trust law and fiduciary duties. The legal and governance framework has failed to prevent principal-agent and conflict of interest problems, including inadequate enforcement and recognition of fiduciary duties and duties of care.

The Australian government's commitment to introducing many of the Royal Commission recommendations, as well as the commitments made by the regulatory agencies, if suitably implemented, should address some of the more glaring problems. However, we still believe that more far-reaching reforms, which draw on international experience, are needed.

In other work, we have recommended rationalisation of regulatory institutions; better use of trust and competition law, and codes of conduct; full and effective disclosure; and the introduction of a new, publicly-administered, fund with a mandate to provide a low cost, passively-managed investment vehicle for Australia's superannuation funds. The latter suggestion would provide a benchmark against which the performance of other funds could be judged, and provide an alternative for those unable or unwilling to make suitable choices for themselves (Morris 2018).

\footnotetext{
${ }^{33}$ Detailed responses are available at https://www.apra.gov.au/sites/default/files/table_with_apras_responses_to_royal_commission_recommendations-v1.pdf

${ }^{34}$ See https://www.afr.com/business/banking-and-finance/rba-treasury-warn-regulatory-response-to-hayne-commission-risks-credit-crunch-20181001-h16322
} 
But in many ways these suggestions deal with the symptoms, rather than the underlying cause, of the malaise which currently infests the Australian financial sector: a lack of basic trustworthiness. To fix this requires a fundamentally different approach to policy. As in the UK, attention needs to be given to how to create strong trustworthiness (ie that driven by a genuine regard for customers and clients) within the sector. We have set out above the actions that need to be taken to establish trustworthiness in the financial system. Achieving this in Australia requires the four steps set out in our Oxford work: full definition of obligations, identification of the responsibilities of different players, establishment of mechanisms to encourage and enforce trustworthiness and proper holding to account.

\section{REFERENCES}

1. Ard, A., and Berg, A. 2010. "Bank Governance: Lessons from the Financial Crisis Response." World Bank. http://siteresources.worldbank.org/EXTFINANCIALSECTOR/Resources/ Note13_Bank_Governance.pdf Accessed 30/8/2019 Last accessed 30/8/2019 (all links last accessed at the same date, if there is no other indication)

2. Bank of England. 2019. "Why are retail banks being 'ring-fenced' and how will this affect me?", https://www. bankofengland.co.uk/KnowledgeBank/why-are-retailbanks-being-ring-fenced-and-how-will-this-affect-me

3. Basel Committee on Banking Supervision. 2019. The Basel Framework, https://www.bis.org/basel_framework/index. htm?export=pdf\&pdfid=15652235539291

4. Borio, C. 2009. "The Financial Crisis of 2007-Macroeconomic and Policy Lessons." Speech delivered at the G20 Workshop on the Global Economy, Mumbai, 24-26 May.

5. Brandweiner, R. 2012. "Trust is a Central Issue for Super Fund Managers." The Australian, Sydney, 6 March.

6. Brown, R. M. C. 2012. "The Public's Lack of Trust Is No Conspiracy Theory-It's Real." Professional Planner, 45: 22.

7. Carney, M. 2013. "Banks Must Rebuild Trust to Ensure Economic Recovery." Financial Post, 3 May. https://business. financialpost.com/news/fp-street/banks-must-rebuildtrust-to-ensure-economic-recovery-carney

8. Commonwealth, 1981. Australian Financial System - Final Report of the Committee of Inquiry, https://treasury.gov. $\mathrm{au} /$ publication/p1981-afs
9. Davies, R. 2014. "A short History of Crisis and Reform." In N. Morris and D. Vines (eds.), Capital Failure: Rebuilding Trust in Financial Services. Oxford: Oxford University Press, pp 79 -99.

10. Dawkins, J. 1992. Security in Retirement: Planning for Tomorrow Today. Canberra: Australian Government Publication Service.

11. de Bruin, B. 2014. "Ethics Management in Banking and Finance." In N. Morris and D. Vines (Eds), Capital Failure: Rebuilding Trust in Financial Services. Oxford: Oxford University Press, pp. 255-276.

12. Department of Treasury, 2014. "The Department of the Treasury's Submission to the Financial System Inquiry." Cth., 3 April.

13. Donald, M. S. 2007. "The Prudent Eunuch: Superannuation Trusteeship in an Environment of Member Investment Choice." University of New South Wales, Australian School of Business.

14. Edeleman, J. 2013. "The Role of Status in the Law of Obligations: Common Callings, Implied Terms and Lessons for Fiduciary Duties." Paper presented at the DePaul University Conference, Chicago, 19-20 July. Published Oxford Scholarship Online, October 2014. https://www.oxfordscholarship. com/view/10.1093/acprof:oso/9780198701729.001.0001/ acprof-9780198701729

15. Edey, M, and Gray, B. 1996. "The Evolving Structure of the Australian Financial System." Reserve Bank of Australia. https://www.rba.gov.au/publications/confs/1996/pdf/ edey-gray.pdf

16. Financial Services Association (FSA), 2009. The Turner Review: A Regulatory Response to the Global Financial Crisis. London: The Financial Services Authority. http:// www.actuaries.org/CTTEES_TFRISKCRISIS/Documents/ turner_review.pdf

17. Financial Services Association (FSA), 2011. The Failure of the Royal Bank of Scotland: Financial Services Authority Board Report, London: Financial Services Authority. https:// www.fca.org.uk/publication/corporate/fsa-rbs.pdf

18. Fraser, B. W. 1994. "Foreign Banks in Australia." Talk by the Governor, B.W. Fraser, to the Overseas Bankers Association of Australia, Melbourne, 17 August. Reserve Bank of Australia Review, September. https://www.rba.gov.au/publications/ bulletin/1994/sep/pdf/bu-0994-3.pdf

19. Getzler, J. 2014. "Financial Crisis and the Decline of Fiduciary Law." In N. Morris and D. Vines (eds.), Capital Failure: Rebuilding Trust in Financial Services. Oxford: Oxford University Press, pp. 193-208. 
20. Glover, J. 2002. "Conflicts of Interest in a Corporate Context." In G.A Acquaah-Gaisie and J. Snip (eds.), Corporate Crime Workshop 2002, 13 February 2002: Papers, Monash University Department of Law and Taxation.

21. Greenspan, A. 2008. Evidence to the House Committee on Oversight and Government Reform. Washington, DC, 23 October.

22. Gold, N. 2014. "Trustworthiness and Motivations." In N. Morris and D. Vines (eds.), Capital Failure: Rebuilding Trust in Financial Services. Oxford: Oxford University Press, pp. 129-153.

23. Hanratty, P. 1997. "The Wallis Report on the Australian Financial System: Summary and Critique." Parliament of Australia Research Paper 16, 23 June. https://www.aph. gov.au/About_Parliament/Parliamentary_Departments/ Parliamentary_Library/pubs/rp/RP9697/97rp16

24. Hewett, J. 2010. “The Great Superannuation Delusion.” The Australian, Sydney, 13 March.

25. House of Commons Treasury (HCT), 2012. The FSA's Report into the Failure of RBS. London: HM Stationery Office.

26. Independent Commission on Banking (ICB), 2011. Independent Commission on Banking. Final Report: Recommendations. London: Dorman Group. https://webarchive.nationalarchives. gov.uk/20120827143059/http://bankingcommission. independent.gov.uk/. Accessed 19 September 2018.

27. Harrington, J.C. 2011. "Ethical Investing in an Age of Excessive Materialistic Self-Interest." In N. Dobos, C. Barry, and T. Pogge (eds.), Global Financial Crisis: The Ethical Issues. Basingstoke Hampshire: Palgrave Macmillan, pp. 82-119.

28. Jaffer, S., Morris, N., and Vines, D. 2014. "Why trustworthiness is important." In N. Morris and D. Vines (eds.), Capital Failure: Rebuilding Trust in Financial Services. Oxford: Oxford University Press, pp. 3-31.

29. Jaffer, S., Morris, N., Sawbridge E., and Vines, D. 2014. "How Changes to the Financial Services Industry Eroded Trust." In N. Morris and D. Vines (eds.), Capital Failure: Rebuilding Trust in Financial Services. Oxford: Oxford University Press, pp. 32-64.

30. Jaffer, S., Knaudt, S., and Morris, N. 2014. "Failures of Regulation and Governance." In N. Morris and D. Vines (eds.), Capital Failure: Rebuilding Trust in Financial Services. Oxford: Oxford University Press, pp. 100-126.

31. Lambert, R. 2014. "Foreword" to Capital Failure: Rebuilding Trust in Financial Services, by Nicholas Morris and David Vines (eds.), Oxford: Oxford University Press, pp. v-ix.

32. McGraph P., Janda, M. 2014. "Senate inquiry demands royal commission into Commonwealth Bank,
ASIC." https://www.abc.net.au/news/2014-06-26/ senate-inquiry-demands-royal-commission-into-asic-cba/5553102

33. Morris, N. 2018. Management and Regulation of Pension Schemes: Australia-A Cautionary Tale. London: Routledge.

34. Morris, N. and D. Vines (eds.). 2014. Capital Failure: Rebuilding Trust in Financial Services. Oxford: Oxford University Press, 2014 (paperback 2016).

35. Murdoch, S. 2018. "Business Financial Services Bankers Thought They Were Geniuses Surviving GFC." The Australian Business Review 4 May. https://www.theaustralian.com.au/ business/financial-services/bankers-thought-they-weregeniuses-surviving-gfc/news-story/3124a07396ba24b91 $5 \mathrm{c} 30 \mathrm{e} 244 \mathrm{~d} 24 \mathrm{~b} 2 \mathrm{ab}$

36. Noe T., Young, H.P. 2014. "The Limits to Compensation in the financial Sector." In N. Morris and D. Vines (eds.), Capital Failure: Rebuilding Trust in Financial Services. Oxford: Oxford University Press, pp. 65-78.

37. O’Brien, J. 2014. "Professional Obligation, Ethical Awareness, and Capital Market Regulation." In N. Morris and D. Vines (eds.), Capital Failure: Rebuilding Trust in Financial Services. Oxford: Oxford University Press, pp. 209-233.

38. Parliamentary Commission on Banking Standards (PCBS), 2013. Changing Banking for Good: First Report of Session 2013-14. London: The Stationery Office. https://www. parliament.uk/documents/banking-commission/Bankingfinal-report-vol-ii.pdf.

39. Parliamentary Joint Committee on Corporations and Financial Services, 2009. Parliament of Australia, Inquiry into Financial Products and Services in Australia: Final Report (Cth.).

40. Pascuzzo, P, 2014. An International Comparison of Pension System Performance in Delivering Adequate Retirement Incomes. Attachment A to "Challenger Response to Financial System Enquiry." http://fsi.gov.au/files/2014/09/ Challenger.docx

41. Pikkarainen, T. Pikkarainen, K., Karjaluoto, H., Pahnila, S. 2004. "Consumer acceptance or online banking: an extension of the technology acceptance model." Internet Research, 14 (3): 224-235.

42. Prime Minister of Australia. 2013. Financial System Inquiry. 20 November. http://www.pm.gov.au/media/2013-11-20/ financial-system-inquiry

43. Rajan, R. 2010. Faultlines: How Hidden Fractures Still Threaten the World Economy. New Jersey: Princeton University Press.

44. Reserve Bank of Australia (RBA), 2014. "Submission to the Financial System Inquiry”, March 2014. 
45. Reserve Bank of Australia (RBA). 2019. "Australian Financial System", Financial Stability Review, April: 43-55. https:// www.rba.gov.au/publications/fsr/2019/apr/pdf/03australian-financial-system.pdf

46. Robertson, 2018. "Financial planning 'doesn't have professional standards, resisting reform." ABC News Analysis, 17 April. http://www.abc.net.au/news/2018-04-16/ financial-planning-lacks-professional-standards/9664134

47. Royal Commission into Misconduct in the Banking, Superannuation and Financial Services Industry, 2019. Final Report. https://financialservices.royalcommission.gov. au/Pages/reports.aspx

48. Select Committee on Superannuation, Parliament of Australia, 2002. Provisions of the Superannuation Legislation Amendment (Choice of Superannuation Funds) Bill 2002 (Cth).

49. Shevlin, 2019. "The Five Hottest Technologies in Banking."

50. https://www.forbes.com/sites/ronshevlin/2019/03/25/ the-5-hottest-technologies-in-banking/\#156b5f9953bd

51. Smith, A. 1776/1976. The Theory of Moral Sentiments. Oxford: Clarendon Press.

52. Slattery, A. 2011. "The Rise and Rise of SMSFs." Speech delivered at the Self-managed Superannuation Funds
Professionals' Association of Australia National Conference, 13 July.

53. UK Government Chief Scientific Adviser, FinTech Futures : The UK as a World Leader in Financial Technologies. A Report by the UK Government Chief Scientific Adviser. https://assets.publishing.service.gov.uk/government/ uploads/system/uploads/attachment_data/file/413095/ gs-15-3-fintech-futures.pdf

54. Verrender, I. 2017. "The Great Australian Bank Subsidy." ABC News Analysis, 27 November. http://www.abc.net. au/news/2017-11-27/how-bad-are-our-banks/9194984

55. Walker, D. 2009. A Review of Corporate Governance in UK Banks and Other Financial Industry Entities: Final Recommendations. London: HM Treasury.

56. Welby, J. Archbishop of Canterbury. 2013. "How do we fix this mess?", 21 April. http://archive.archbishop.canterbury. brix.fatbeehive.com/articles.php/5050/how-do-we-fix-thismess-archbishop-justin-on-restoring-trust-and-confidenceafter-the-crash

57. Wolf, M. 2011. "Comment on Andrew G. Haldane, 'Control Rights (and Wrongs)'". Speech given at the Wincott Annual Memorial Lecture, 24 October. http://www.wincott.co.uk/ lectures/2011.html. 